\title{
Prenatal oestrogen-testosterone balance as a risk factor of migraine in adults
}

\author{
Magdalena Kobus ${ }^{1 *}$ (D), Aneta Sitek', Bogusław Antoszewski², Jacek Rożniecki ${ }^{3}$, Jacek Pełka ${ }^{4}$ and Elżbieta Żądzińska ${ }^{1,5}$
}

\begin{abstract}
Background: Migraine is a common neurological disease with extremely debilitating, but fully reversible symptoms. Women suffer from migraine more often than men. It was assumed that fluctuation of oestrogen level during menstrual cycle is one of many factors responsible for more frequent migraine attacks. The second-to-fourth digit ratio (2D:4D) is considered as an indicator of prenatal sex steroids. Balance of prenatal androgens (testosterone) and oestrogen has been studied in numerous diseases that are affected by hormones. However, the relationship between migraine and the sex steroids balance in prenatal development is still unexplained.

The aim of this paper is to provide an evidence of relationship between prenatal oestrogen and testosterone exposure following 2D:4D digit ratio, and migraine prevalence in adults.

Methods: We examined a group of 151 adults (33 males, 118 females) with migraine and a control group of 111 adults (45 males, 66 females). 2D:4D digit ratio of both hands was measured using sliding Vernier calliper.

Results: Significant differences were found in the right hand. Female migraineurs had lower value of 2D:4D ratio than the control group and the right 2D:4D was lower than left 2D:4D ( $\Delta 2 \mathrm{D}: 4 \mathrm{D})$, suggesting prenatal testosterone dominance. The opposite relationship was observed in males. Male migraineurs had higher value of 2D:4D ratio and $\Delta 2 \mathrm{D}: 4 \mathrm{D}$ was greater than the control group, suggesting prenatal oestrogen dominance.

Conclusions: Our results suggest that depending on sex, different proportion of prenatal sex steroids might be a risk factor of migraine in adults. Women with migraine were presumably exposed in prenatal life to higher testosterone levels relative to oestrogen, while men with migraine were probably exposed in prenatal life to higher levels of oestrogen relative to testosterone.
\end{abstract}

Keywords: Migraine, Sex hormones, Sex steroids, Digit ratio, 2D:4D, Prenatal, Oestrogen, Testosterone, Intrauterine development

\section{Background}

Migraine is one of the most common primary headaches next to tension-type headache. International Headache Society in Headache classification (ICHD-3) distinguishes several types of migraine. Two major types are migraine without and with aura. Aura symptoms are fully reversible and they can be visual, sensory, speech, motor, brainstem and retinal [1]. Numerous epidemiological studies report

\footnotetext{
* Correspondence: magdalena.kobus@biol.uni.lodz.pl

'Department of Anthropology, Faculty of Biology and Environmental Protection, University of Lodz, 90-237 Lodz, Poland

Full list of author information is available at the end of the article
}

widespread prevalence of migraine and its burdensome health effects and socio-economic costs [2-4].

Migraine attacks affect over $11 \%$ of the world's population and occur 3 times more often in women than in men [5-7]. It should be underlined that also about $10 \%$ of children suffer for migraine. It means that in some cases migraine influences quality of life already in childhood $[4,8]$. Nevertheless, recent studies have shown that migraine is still underdiagnosed and undertreated $[2,9]$.

Research about pathophysiological mechanisms of migraine evolve continuously due to the fact that migraine is probably a multifactorial disease [10-14]. Migraine is

(C) The Author(s). 2021 Open Access This article is licensed under a Creative Commons Attribution 4.0 International License, which permits use, sharing, adaptation, distribution and reproduction in any medium or format, as long as you give appropriate credit to the original author(s) and the source, provide a link to the Creative Commons licence, and indicate if changes were made. The images or other third party material in this article are included in the article's Creative Commons licence, unless indicated otherwise in a credit line to the material. If material is not included in the article's Creative Commons licence and your intended use is not permitted by statutory regulation or exceeds the permitted use, you will need to obtain permission directly from the copyright holder. To view a copy of this licence, visit http://creativecommons.org/licenses/by/4.0/ The Creative Commons Public Domain Dedication waiver (http://creativecommons.org/publicdomain/zero/1.0/) applies to the data made available in this article, unless otherwise stated in a credit line to the data. 
definitely dependent on genetic predisposition [15-17], while attacks can be triggered by various endogenous and environmental factors [18-21]. Prenatal factors of migraine have not been widely studied so far [22-24]. The authors of this paper aimed to analyse the influence of prenatal sex steroid exposure (2D:4D ratio) as a potential risk factor of migraine.

The ratio of 2nd and 4th digit length (2D:4D) in human hand is a well-known method to assess sex steroids proportions during prenatal life. Males usually have lower ratio (due to longer 4th digit) than females (due to shorter 4th digit) [25]. The research with mice conducted by Zheng and Cohn confirmed hypothesis that activity of androgen and oestrogen receptors in prenatal life has influence of a digit growth. Inactivation of androgen receptor decreased growth of 4th digit (led to a feminized 2D:4D) while inactivation of oestrogen receptor $\alpha$ increased growth of 4th digit (led to a masculinized 2D:4D). 4D has higher levels of both receptors and their activity influences 2D:4D digit ratio by regulating expression of 19 skeletogenic genes [25]. Difference between 2D:4D $R$ and $L(\Delta 2 D: 4 D)$ is also sexually dimorphic and tends to be negative in males and positive in females [26]. Low $\triangle 2 \mathrm{D}: 4 \mathrm{D}$ is thought to be another correlate of high prenatal testosterone levels and low prenatal oestrogen levels [27]. $\Delta 2 \mathrm{D}: 4 \mathrm{D}$ was first considered to be a correlate of prenatal sex steroids by Manning et al. [28] and further by Manning \& Peters in studies concerned with handedness [29]. The 2D:4D digit ratio seems to be the risk factor of many diseases in different populations, among others with breast cancer [30], coronary heart disease [31], ischemic stroke [32] and lung cancer [33].

Geschwind and Galaburda (1985) were the first who hypothesised that prenatal testosterone slows down the growth of certain areas of the left hemisphere and promotes the growth of the homologous areas of the right hemisphere. Researchers linked high prenatal testosterone levels with aetiology of e.g. autism and migraine [34]. The issue whether 2D:4D levels are associated with autism is still under investigation [35-41]. Until now the problem of the relationship between digit ratio and primary headaches has been addressed only in 1 original publication. Xie et al. showed in Chinese population that females with migraine or with tension-type headache had lower 2D:4D ratio than females in the control group without these primary headaches [22].

The main aim of this study was to evaluate if proportion of sex steroids exposure during pregnancy is a possible risk factor of migraine in Polish population.

\section{Material and methods}

We recruited patients of Norbert Barlicki Memory University Teaching Hospital No. 1 in Lodz. The study included two groups of adults. Migraineurs were recruited from the outpatient neurological clinic of the hospital (151 participants aged 18-76 years), while patients without migraine and other headaches declared were recruited from other hospital clinics (111 participants aged 21-74 years). Data collection started in 2019 and ended in 2020.

Measurements of the length of the 2nd and 4th digits were performed by a professional staff from the Department of Anthropology of the University of Lodz. Sliding Vernier calliper was used in accordance with standard anthropometric procedure of Martin measurements [42]. The measurements of digit lengths in both hands was made between pseudophalangion and dactylion points [43]. Direct finger measurement is accurate method to determine 2D:4D R [44, 45].

Based on these measurements the 2D:4D digit ratios and the difference of 2D:4D ratio between the hands $(\Delta 2 \mathrm{D}: 4 \mathrm{D}=2 \mathrm{D}: 4 \mathrm{D} \mathrm{R}-2 \mathrm{D}: 4 \mathrm{D} \mathrm{L})$ were calculated.

Statistical analysis of the results was performed in the STATISTICA 13.0 program. All statistical calculations were carried out in spreadsheets after anonymization of the data. Age distribution, 2D:4D R \& L digit ratios and $\Delta 2 \mathrm{D}: 4 \mathrm{D}$ normality were assessed using the Shapiro-Wilk test. Age distribution was skewed - Mann-Whitney test (Z) was used to assess intergroup and sex differences of this trait. 2D:4D R, 2D:4D L and $\Delta 2 \mathrm{D}: 4 \mathrm{D}$ had normal distributions. Relationship 2D:4D R \& L with age and $\Delta 2 \mathrm{D}: 4 \mathrm{D}$ with age were accessed by Spearman's rank correlation coefficient (R). Mean values of 2D:4D R \& $L$ and $\Delta 2 \mathrm{D}: 4 \mathrm{D}$ in women and men as well as in the migraine group and the control group were compared using contrast analysis. Due to the fact that during contrast analysis multiple comparisons were made probability of making a type I error could increase. On the other hand applying stringent multiple testing corrections (Bonferroni correction; Holm's Sequential Bonferroni Procedure) may increase the probability of making a type II error. In order to make a reasonable decision regarding significance of testing differences probability of obtaining a certain number of statistically significant tests among the total number of performed multiple comparisons was calculated according to the following formula:

$$
\mathrm{P}_{\mathrm{B}}(\mathrm{A})=\alpha^{\mathrm{A}}(1-\alpha)^{\mathrm{B}-\mathrm{A}}
$$

where: A- number of statistically significant results, $B$ - total number of tests performed, $\alpha$ - significance level [46]. Odds ratios (ORs) were estimated with 95\% confidence intervals (CIs). Cohen's effect sizes (Cohen's $\Delta$ ) were calculated using Online Effect Size Calculator (https://www.socscistatistics.com/effectsize/ default3.aspx). 


\section{Results}

Median age for females with migraine was 41,5 years (interquartile range from 29 to 51) while for females in the control group - 43 years (IQR 31-51). Half of males in the migraine group were under 36 (IQR 27-50) and half of males in the control group were under 42 (IQR 31-46). No statistically significant differences were found in age between sexes and the both study groups (F/M) also (Table 1).

There was no correlation between age and 2D:4D R \& $\mathrm{L}$ and $\Delta 2 \mathrm{D}: 4 \mathrm{D}$ in the both female and the male. No statistically significant correlation was also found between age and 2D:4D R \& $\mathrm{L}$ and $\Delta 2 \mathrm{D}: 4 \mathrm{D}$ in the female and the male separately in both study groups (Table 2).

Table 3 presents average values and standard deviations of $2 \mathrm{D}: 4 \mathrm{D} \mathrm{R} \& \mathrm{~L}$ and $\triangle 2 \mathrm{D}: 4 \mathrm{D}$ in the both study groups (F/M). Table 4 presents Cohen's effect sizes calculated to assess the magnitude of the mean differences and most of them was medium.

As a result of contrast analysis eight significant results $(\alpha=0.05)$ were found in twelve test performed (Table 4$)$. Probability of obtaining such number of significant differences among twelve multiple comparisons $\mathrm{P}_{\mathrm{B}}(\mathrm{A})=$ $1,57 \mathrm{E}-08$ is very low. Therefore, it was assumed that the observed differences reflected actual biological effects.

2D: 4D $\mathrm{R}$ digit ratio showed no dimorphic differences in the migraine group $(p=0.500)$, whereas in the control group differences were statistically significant $(p<0.001)$ and their direction were as expected (females had higher mean of 2D:4D $R$ than males).

Comparison 2D:4D $R$ in both study groups showed that females with migraine had lower 2D:4D $R$ than females in the control group $(p<0.001)$, whereas males with migraine had higher 2D:4D $\mathrm{R}$ than males in the control group $(p=0.007)$. Consequently the risk of migraine was increased in females with lower 2D:4D $R$ (OR 2.98, 95\% CI 1.54-5.76) and among males the risk of migraine was increased when 2D:4D $\mathrm{R}$ was higher (OR 1.48, 95\% CI 0.49-4.46) (Tables 3, 4; Fig. 1).
2D: 4D L digit ratio showed no dimorphic differences in the migraine group $(p=0.091)$ and it was differentiated between females and males in the control group $(p=0.036)$, presenting as expected higher values for females and lower values for males. At the same time 2D: 4D L turned out to be similar in females in the both study groups $(p=0.793)$ and in males in the both study groups ( $p=0.889$ ) (Tables 3, 4, Fig. 2).

$\triangle 2 \mathrm{D}: 4 \mathrm{D}$ showed sexual dimorphism in both study groups, but in females with migraine it was characterized by lower values than in males with migraine $(p=0.027)$, whereas in the control group the opposite direction of the differences was observed $(p<0.001)$. Females with migraine had lower $\Delta 2 \mathrm{D}: 4 \mathrm{D}$ than females in the control group $(p<0.001)$. Males with migraine had higher $\Delta 2 \mathrm{D}: 4 \mathrm{D}$ than males in the control group $(p=0.014)$ (Tables 3, 4; Fig.3).

\section{Discussion}

In the prenatal period a foetus is more sensitive to variety of factors, including hormonal disturbances [47-49]. Intrauterine hormonal environment is probably associated with a number of diseases in adulthood, and migraine can be considered as one of them. Migraine is a common health problem and can be determined already in early ontogenesis, affecting about $10 \%$ of children and adolescents [4, 8]. Manning and Bundred (2000) have drawn attention to a role of prenatal hormonal environment in developing several diseases, and suggested 2D: 4D digit ratio as a potential predictor of them [50]. 2D: 4D ratios are stable during postnatal ontogenesis and are established already at the prenatal stage of the development. Lower values of 2D:4D digit ratio are linked with high testosterone levels during pregnancy. Testosterone has an impact on the central nervous system by slowing down the growth of the left hemisphere (and promotes the growth of the right hemisphere simultaneously). Geschwind and Galaburda suggested that there is an association between prenatal testosterone migraine and

Table 1 Statistical age characteristics for the study group and the control group (F/M)

\begin{tabular}{llll}
\hline Characteristic & Migraine group & Control group & Migraine group vs Control group \\
\hline Females & & & $Z$ \\
$\mathrm{n}$ & 118 & 66 & $\mathrm{Z}=-0.52 ; p=0.604$ \\
Median & 41.5 & 43.0 & \\
$\mathrm{Q}_{25}-\mathrm{Q}_{75}$ & $29-51$ & $31-51$ & $\mathrm{Z}=-0.55 ; p=0.581$ \\
Males & & 45 & \\
$\mathrm{n}$ & 33 & 42.0 & \\
Median & 36.0 & $31-46$ & \\
$\mathrm{Q}_{25}-\mathrm{Q}_{75}$ & $27-50$ & $\mathrm{Z}=0.77 ; p=0.440$ & \\
Females vs Males & $\mathrm{Z}=0.82 ; p=0.410$ &
\end{tabular}

$n$-sample size, $Q_{25}-Q_{75}$ - interquartile range; Z-values Manna-Whitney for $n>20$, p- probability 
Table 2 Correlation between age and 2D:4D digit ratios

\begin{tabular}{|c|c|c|c|c|c|c|c|c|}
\hline \multirow[t]{2}{*}{ Groups / Sex } & & \multirow[t]{2}{*}{$n$} & \multicolumn{2}{|c|}{ 2D:4D R \& age } & \multicolumn{2}{|c|}{ 2D:4D L \& age } & \multicolumn{2}{|c|}{$\Delta 2 \mathrm{D}: 4 \mathrm{D} \&$ age } \\
\hline & & & $\mathrm{R}$ & $p$ & $\bar{R}$ & $P$ & $\bar{R}$ & $p$ \\
\hline Females & & 184 & -0.08 & 0.290 & -0.06 & 0.418 & -0.03 & 0.650 \\
\hline Males & & 78 & -0.01 & 0.977 & 0.06 & 0.574 & 0.04 & 0.703 \\
\hline \multirow[t]{2}{*}{ Migraine group } & $F$ & 118 & -0.05 & 0.596 & -0.003 & 0.976 & 0.002 & 0.981 \\
\hline & $M$ & 33 & 0.05 & 0.780 & -0.06 & 0.747 & 0.12 & 0.501 \\
\hline \multirow[t]{2}{*}{ Control group } & $\mathbf{F}$ & 66 & -0.20 & 0.105 & -0.12 & 0.321 & -0.11 & 0.374 \\
\hline & $M$ & 45 & -0.07 & 0.655 & -0.15 & 0.320 & 0.23 & 0.128 \\
\hline
\end{tabular}

n-sample size, R- Spearman's rank correlation coefficient, p- probability

left-handedness [34]. Masculinized 2D:4D has been associated in women with breast cancer [30], lung cancer [33], and carpal tunnel syndrome [51] and prostate cancer in men [52]. Feminized 2D:4D has been linked to heart disease in men [53] and greater pain resistance in women [54].

The influence of the sexual dimorphism on the prevalence of migraine is probably multifactorial, but many researchers suggest an important role of sex hormones $[55,56]$. However, the role of sex steroids at the prenatal stage is not fully understood.

The aforementioned data on prenatal hormonal environmental conditions as a risk factor of migraine published by Xie et al. showed that prenatal testosterone dominance can lead to increased prevalence of migraine in females [22]. In the Chinese population women with masculinized digit ratio 2D:4D R \& $\mathrm{L}$ tended to suffer more from migraine and tension type headache $(\mathrm{TTH})$, but there was no such relationship in males [22]. The results of our study suggest that prenatal sex steroids exposure has influence on the risk of migraine both in women and in men. Our results in the group of female migraineurs were similar to the data of Xie et al. and thus masculinized digit ratios were associated with migraine prevalence $(\mathrm{OR}=2.98)$, but significant relationship was noticed only in the right hand. It should be emphasized however, that the right hand is regarded as a better indicator of androgenisation than the left one
[25]. What is new what we have shown is that prenatal oestrogen exposure probably can also increase the risk of migraine, and that such relationship is sex-dependent and observed only in male migraineurs in the right hand $(\mathrm{OR}=1.48)$.

The results of our study showed that both 2D:4D digit ratio and $\Delta 2 \mathrm{D}: 4 \mathrm{D}$ were significantly associated with migraine. The $\Delta 2 \mathrm{D}: 4 \mathrm{D}$ was first considered to be an additive correlate of prenatal oestrogen-testosterone balance by Manning et al. in 2000 [28]. Low $\Delta 2 \mathrm{D}: 4 \mathrm{D}$ is associated with prenatal testosterone dominance. Its value tends to be negative in men (lower 2D:4D R than 2D:4D $\mathrm{L}$ ) and positive in women (higher 2D:4D $R$ than 2D:4D L) [27]. The results of this study showed such sex differences pattern in the control group (male $\Delta 2 \mathrm{D}: 4 \mathrm{D}<\mathrm{fe}$ male $\Delta 2 \mathrm{D}: 4 \mathrm{D}$ ). The opposite result was found in the migraine group (male $\Delta 2 \mathrm{D}: 4 \mathrm{D}>$ female $\Delta 2 \mathrm{D}: 4 \mathrm{D}$ ). Our data provide the new valuable link between high prenatal oestrogen exposure in men and migraine.

Study by Manning \& Peters (2009) showed that low $\triangle 2 \mathrm{D}: 4 \mathrm{D}$ is connected with left-handedness [29]. Left hand preference is also associated with migraine [34]. In 1982 Geshwind and Behan reported higher frequency of left-handed individuals in migraineurs [57]. The latest study published in 2021 showed that handedness is also possibly connected with pain localization during migraine attacks. Over $60 \%$ attacks characterized by pain on the right side were related to the right-handedners

Table 3 Statistical characteristics of 2D:4D in migraine and control groups

\begin{tabular}{|c|c|c|c|c|c|c|}
\hline \multirow[t]{2}{*}{ Characteristic } & \multicolumn{3}{|c|}{ Migraine group } & \multicolumn{3}{|c|}{ Control group } \\
\hline & $n$ & $x$ & SD & $n$ & $x$ & SD \\
\hline \multicolumn{7}{|l|}{ Females } \\
\hline 2D:4D R & 118 & 0,9869 & 0,0292 & 66 & 10,056 & 0,0297 \\
\hline 2D:4D L & & 0,9958 & 0,0293 & & 0,9969 & 0,0304 \\
\hline$\Delta 2 \mathrm{D}: 4 \mathrm{D}$ & & $-0,0089$ & 0,0324 & & 0,0087 & 0,0299 \\
\hline \multicolumn{7}{|l|}{ Males } \\
\hline $2 \mathrm{D}: 4 \mathrm{D} R$ & 33 & 0,9907 & 0,0335 & 45 & 0,9726 & 0,0233 \\
\hline 2D:4D L & & 0,9864 & 0,0222 & & 0,9855 & 0,0244 \\
\hline$\Delta 2 \mathrm{D}: 4 \mathrm{D}$ & & 0,0043 & 0,0348 & & $-0,0129$ & 0,0189 \\
\hline
\end{tabular}


Table 4 Contrast analysis results

\begin{tabular}{|c|c|c|c|c|c|c|c|c|c|c|c|c|}
\hline \multirow[t]{3}{*}{ Characteristic } & \multicolumn{6}{|c|}{ Females vs Males } & \multicolumn{6}{|c|}{ Migraine group vs Control Group } \\
\hline & \multicolumn{2}{|c|}{ Migraine group } & \multirow[t]{2}{*}{ Cohen's $\Delta$} & \multicolumn{2}{|c|}{ Control Group } & \multirow[t]{2}{*}{$\overline{\text { Cohen's } \Delta}$} & \multicolumn{2}{|c|}{ Females } & \multirow[t]{2}{*}{ Cohen's $\Delta$} & \multicolumn{2}{|c|}{ Males } & \multirow[t]{2}{*}{ Cohen's $\Delta$} \\
\hline & $\mathbf{F}$ & $\mathbf{p}$ & & $\mathbf{F}$ & $\mathbf{p}$ & & $\mathbf{F}$ & $\mathbf{p}$ & & $\mathbf{F}$ & $\mathbf{p}$ & \\
\hline 2D:4D R & 0.46 & 0.500 & 0.12 & 34.55 & $<0.001$ & 1.24 & 17.64 & $<0.001$ & 0.64 & 7.41 & 0.007 & 0.63 \\
\hline $2 D: 4 D L$ & 2.88 & 0.091 & 0.36 & 4.42 & 0.036 & 0.41 & 0.07 & 0.793 & 0.04 & 0.02 & 0.889 & 0.04 \\
\hline$\Delta 2 \mathrm{D}: 4 \mathrm{D}$ & 4.94 & 0.027 & 0.39 & 13.63 & $<0.001$ & 0.86 & 14.35 & $<0.001$ & 0.56 & 6.17 & 0.014 & 0.61 \\
\hline
\end{tabular}

F-Fishera-Snedecor test value; $\mathrm{p}$ - probability, Note - statistically significant differences are marked in bold

(62.8\%) and attacks characterized by pain on the left side were related to the left-handedners (63.5\%) [58].

The fact of a relationship between migraine and sex hormones levels has been recognized by many epidemiological studies. Especially in women, oestrogen fluctuations are identified as a risk factor of migraine and migraine attacks [56]. Pourabolghasem et al. suggested that there is no evidence that higher levels of male sex hormones (mainly testosterone) in female migraineurs with polycystic ovary syndrome (PCOS) intensify migraine attacks [59]. Glintborg et al. reported that migraine was more prevalent in PCOS females [60]. SirPeterman et al. showed that among pregnant women with PCOS peripheral serum androgen concentrations were significantly elevated and constituted a potential source of excessive androgen for a foetus [61]. PCOS belongs to the most common endocrine disorders affecting women of childbearing potential, and women suffering from it who wish to become pregnant or already pregnant women should be monitored with special care.
Previously it has been shown that oestrogen can influence initiating migraine attack in women [62]. Recently it has turned out that the female sex hormones also affect male migraineurs when oestrogen is elevated - van Oosterhout reported that men with migraine (with at least 3 episodes per month) had increased levels of the oestrogen (E2) and androgen deficiency at the same time $(N=17)$ [63]. Shields et al. reported in their pilot study that men with chronic migraine $(N=14)$ also had decreased testosterone levels [64]. Our study indirectly reveals that oestrogen-testosterone balance in men with migraine is also associated with oestrogen dominance, but already at the prenatal stage of development. The role of oestrogen and testosterone in modulating migraine deserves further investigations whether there is a link between prenatal exposure and postnatal levels or not.

There is a need of indicators that would be helpful in assessing lifelong risks of prenatal disturbances that can increase migraine prevalence. Hormonal environment in utero seems to play significant but unexplored role in

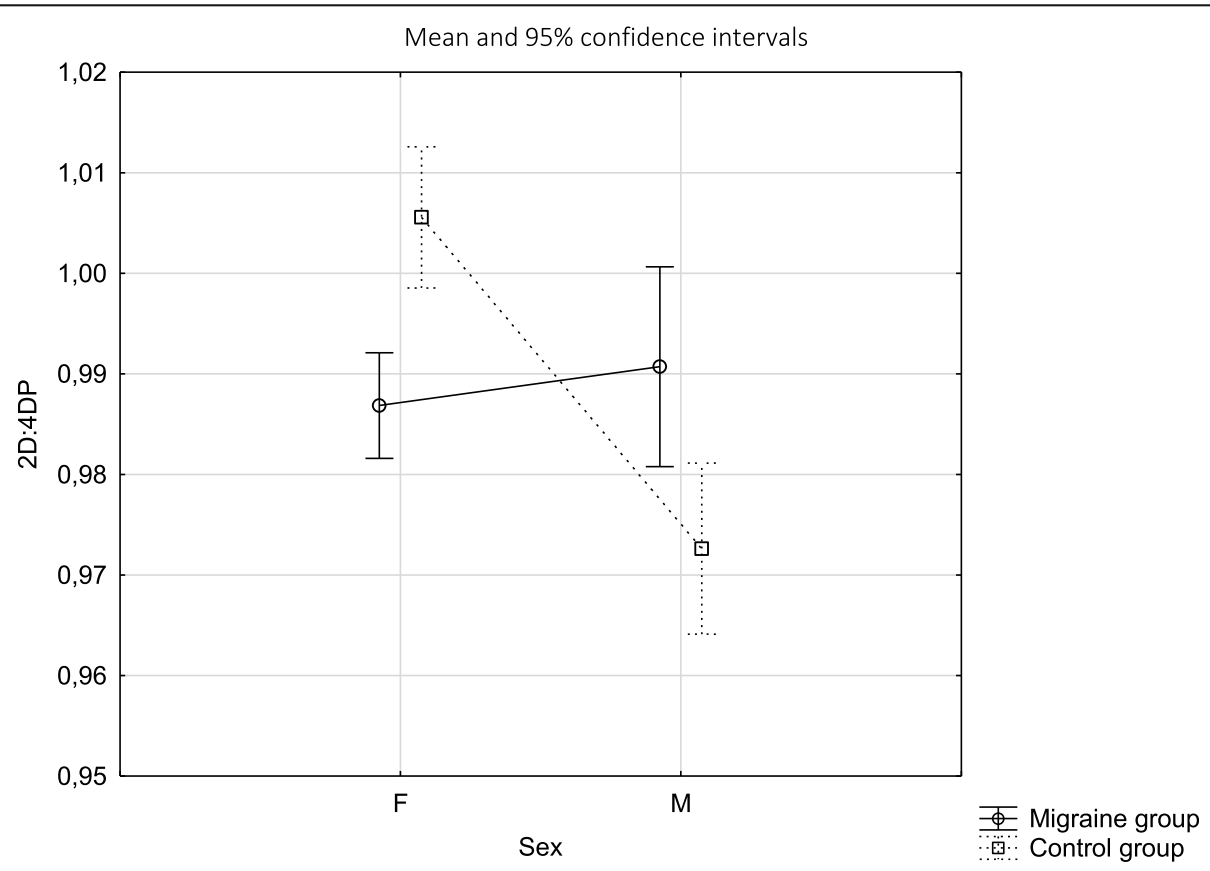

Fig. 1 2D:4D of the right hand depending on sex and the study group 


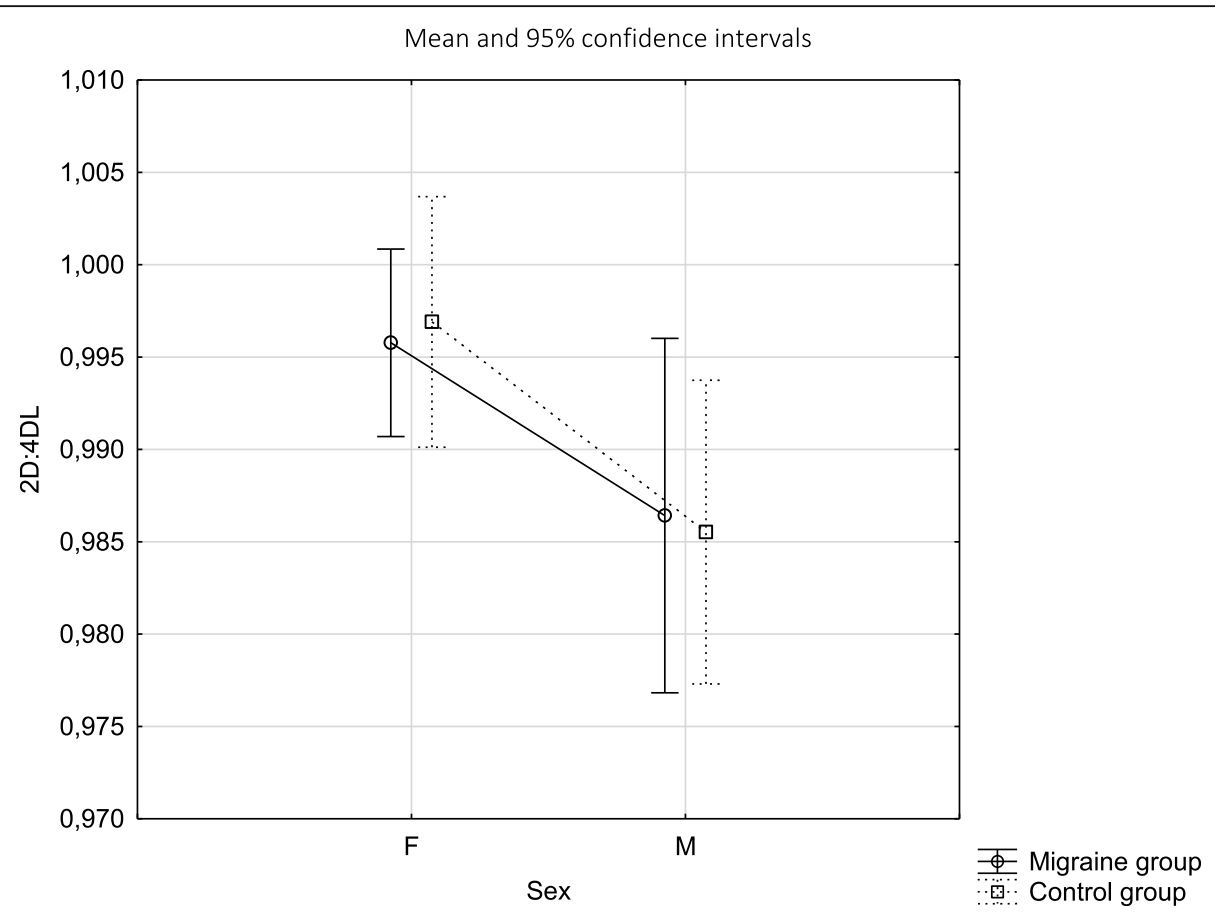

Fig. 2 2D:4D of the left hand depending on sex and the study group

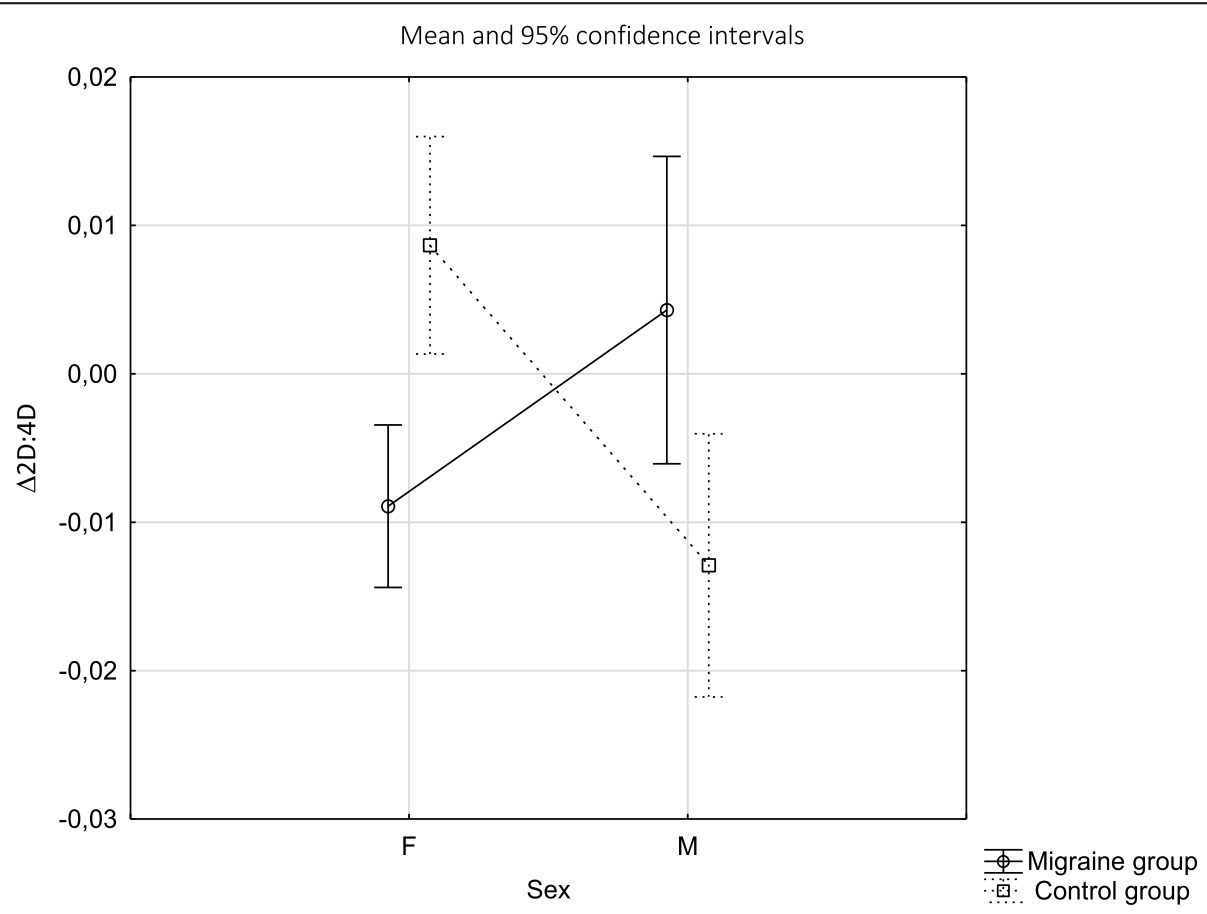

Fig. 3 Difference between 2D:4D R and 2D:4D L depending on sex and the study group 
developing migraine. Prenatal testosterone and estrogen levels estimated indirectly by $2 \mathrm{D}: 4 \mathrm{D}$ digit ratio can be considered as one of such indicators for both sexes.

\section{Conclusions}

Although the relationship between migraine and sex hormones has already been demonstrated many times, pathophysiology of this relationship has not yet been fully explained. The role of sex steroids at prenatal stage for development of migraine is not understood. Migraine can be "sex-steroid-programmed" in foetal life differently in men and women. Increased prenatal testosterone levels in women significantly correlated with the prevalence of migraine. In men, the opposite correlation was observed: males with presumably decreased testosterone levels in prenatal life are supposed to suffer more probably from migraine in adulthood. This research should be continued by expanding study groups and analysing correlations in different populations.

\section{Limitations}

Study was limited by a small sample of men who suffer from migraine. Patients were from quite homogenous population in Poland.

\section{Acknowledgements}

Not applicable.

\section{Authors' contributions}

Conception - BA, EŻ, JR; design of the work - AS, BA, EŻ, JR, MK; acquisition AS, JP, MK; analysis - AS, EZ; interpretation of data - AS, EZZ, MK; draft version - AS, EŻ, MK; critical comments - AS, BA, EŻ, JR. The authors read and approved the final manuscript.

\section{Funding}

Publication's printing cost was co-financed by the European Union from the European Social Fund under the "InterDOC-STARt" project (POWR.03.02.0000-I033/16-00).

\section{Availability of data and materials}

The datasets used in the current study available from the corresponding author on request.

\section{Declarations}

\section{Ethics approval and consent to participate}

The study was conducted according to the guidelines of the Declaration of Helsinki and approved by the Ethical Commission at the University of Lodz (no. 16/KBBN-UŁ/III/2018). Written informed consent was obtained from all participants after receiving detailed study information.

\section{Consent for publication}

Not applicable.

\section{Competing interests}

The authors declare that they have no competing interests.

\section{Author details}

${ }^{1}$ Department of Anthropology, Faculty of Biology and Environmental Protection, University of Lodz, 90-237 Lodz, Poland. '2Department of Plastic, Reconstructive and Aesthetic Surgery, Institute of Surgery, Medical University of Lodz, Lodz, Poland. 'Department of Neurology, Stroke and Neurorehabilitation, Medical University of Lodz, Lodz, Poland. ${ }^{4}$ Department of Neurology, Norbert Barlicki Memory University Teaching Hospital, Lodz,
Poland. ${ }^{5}$ Biological Anthropology and Comparative Anatomy Research Unit, School of Medicine, The University of Adelaide, Adelaide, South Australia 5005, Australia.

Received: 22 June 2021 Accepted: 7 September 2021

Published online: 07 October 2021

\section{References}

1. Headache Classification Committee of the International Headache Society (2018) The International Classification of Headache Disorders, 3rd edition. Cephalalgia, pp 1-211. https://doi.org/10.1177/0333102417738202

2. Ryvlin P, Skorobogatykh K, Negro A, Sanchez-De La Rosa R, Israel-Willner H, Sundal C et al (2021) Current clinical practice in disabling and chronic migraine in the primary care setting: results from the European My-LIFE anamnesis survey. BMC Neurol 21(1):1

3. Martinez-Fernandez A, Rueda Vega M, Quintas S, de Toledo HM (2020) Diaz de Teran J, Latorre Gonzalez G, et al. psychosocial repercussion of migraine: is it a stigmatized disease? Neurol Sci 41(8):2207-2213. https://doi.org/10.1 007/s10072-020-04332-6

4. Koller LS, Diesner SC, Voitl P (2019) Quality of life in children and adolescents with migraine: an Austrian monocentric, cross-sectional questionnaire study. BMC Pediatr 19(1):164. https://doi.org/10.1186/s12887-019-1537-0

5. Dodick DW (2006) Clinical practice. Chronic daily headache. N Engl J Med 354(2):158-165. https://doi.org/10.1056/NEJMcp042897

6. Stephen L, Hauser SAJ (2012) Harrison Neurologia w medycynie klinicznej. Czelej, Lublin, p 452

7. Buse DC, Loder EW, Gorman JA, Stewart WF, Reed ML, Fanning KM, Serrano D, Lipton RB (2013) Sex differences in the prevalence, symptoms, and associated features of migraine, probable migraine and other severe headache: results of the American Migraine Prevalence and Prevention (AMPP) study. Headache. 53(8):1278-1299. https://doi.org/10.1111/head.12150

8. Barnes NP (2015) Migraine headache in children. BMJ Clinical Evidence vol. 2015 PMID: 26044059; PMCID: PMC4456852

9. Domitrz I, Lipa A, Rozniecki J, Stepien A, Kozubski W (2020) Treatment and management of migraine in neurological ambulatory practice in Poland by indicating therapy with monoclonal anti-CGRP antibodies. Neurol Neurochir Pol 54(4):337-343. https://doi.org/10.5603/PJNNS.a2020.0054

10. Kokoti L, Al-Karagholi MA, Ashina M (2020) Latest insights into the pathophysiology of migraine: the ATP-sensitive potassium channels. Curr Pain Headache Rep 24(12):77. https://doi.org/10.1007/s11916-020-00911-6

11. Gross EC, Lisicki M, Fischer D, Sandor PS, Schoenen J (2019) The metabolic face of migraine - from pathophysiology to treatment. Nat Rev Neurol 15(11):627-643. https://doi.org/10.1038/s41582-019-0255-4

12. Charles $A$ (2018) The pathophysiology of migraine: implications for clinical management. Lancet Neurol 17(2):174-182. https://doi.org/10.1016/S14 74-4422(17)30435-0

13. Vetvik KG, MacGregor EA (2017) Sex differences in the epidemiology, clinica features, and pathophysiology of migraine. Lancet Neurol 16(1):76-87. https://doi.org/10.1016/S1474-4422(16)30293-9

14. Noseda R, Burstein R (2013) Migraine pathophysiology: anatomy of the trigeminovascular pathway and associated neurological symptoms, CSD, sensitization and modulation of pain. Pain 154(Suppl 1) p S44-S53. https:// doi.org/10.1016/j.pain.2013.07.021

15. Gotra P, Bhardwaj N, Ludhiadch A, Singh G, Munshi A (2021) Epilepsy and Migraine Shared Genetic and Molecular Mechanisms: Focus on Therapeutic Strategies. Mol Neurobiol 58, 3874-3883. https://doi.org/10.1007/s12035-021-02386-x

16. Quintas M, Neto JL, Sequeiros J, Sousa A, Pereira-Monteiro J, Lemos C, Alonso I (2020) Going deep into synaptic vesicle machinery genes and migraine susceptibility - a case-control association study. Headache. 60(10): 2152-2165. https://doi.org/10.1111/head.13957

17. Chen SP, Fuh JL, Chung MY, Lin YC, Liao YC, Wang YF, Hsu CL, Yang UC, Lin MW, Chiou JJ, Wang PJ, Chen PK, Fan PC, Wu JY, Chen YT, Kao LS, ShenJang Fann C, Wang SJ (2018) Genome-wide association study identifies novel susceptibility loci for migraine in Han Chinese resided in Taiwan. Cephalalgia. 38(3):466-475. https://doi.org/10.1177/0333102417695105

18. Guidetti V, Faedda N, Siniatchkin M (2016) Migraine in childhood: biobehavioural or psychosomatic disorder? J Headache Pain 17(1):82. https://doi.org/10.1186/s10194-016-0675-0

19. Ravid S (2014) Migraine \& paediatric obesity: a plausible link? Indian J Med Res 139(3):343-348 
20. Hagen K, Asberg AN, Stovner L, Linde M, Zwart JA, Winsvold BS et al (2018) Lifestyle factors and risk of migraine and tension-type headache. Follow-up data from the Nord-Trondelag health surveys 1995-1997 and 2006-2008. Cephalalgia. 38(13):1919-1926. https://doi.org/10.1177/0333102418764888

21. Schwedt TJ, Alam A, Reed ML, Fanning KM, Munjal S, Buse DC, Dodick DW, Lipton RB (2018) Factors associated with acute medication overuse in people with migraine: results from the 2017 migraine in America symptoms and treatment (MAST) study. J Headache Pain 19(1):38. https://doi.org/10.11 86/s10194-018-0865-z

22. Xie W, He M, Liu R, Dong Z, Xie J, Wang D, Yu S (2015) The second to fourth digit ratio (2D:4D): a risk factor of migraine and tension-type headache. $J$ Headache Pain 16(1):11. https://doi.org/10.1186/s10194-015-0494-8

23. Waldie KE, Thompson JM, Mia Y, Murphy R, Wall C, Mitchell EA (2014) Risk factors for migraine and tension-type headache in 11 year old children. J Headache Pain 15(1):60. https://doi.org/10.1186/1129-2377-15-60

24. Borte S, Winsvold BS, Stensland SO, Smastuen MC, Zwart JA (2017) The effect of foetal growth restriction on the development of migraine and tension-type headache in adulthood. HUNT Study PLoS One 12(4):e0175908. https://doi.org/10.1371/journal.pone.0175908

25. Zheng Z, Cohn MJ (2011) Developmental basis of sexually dimorphic digit ratios. Proc Natl Acad Sci U S A 108(39):16289-16294. https://doi.org/10.1 073/pnas.1108312108

26. Manning JT, Fink B (2008) Digit ratio (2D:4D), dominance, reproductive success, asymmetry, and sociosexuality in the BBC internet study. Am J Hum Biol 20(4):451-461. https://doi.org/10.1002/ajhb.20767

27. Manning JT (2002) Digit ratio: a pointer to fertility, Behavior and Health Rutgers University Press, pp 21-22

28. Manning JT, Trivers RL, Thornhill R, Singh D (2000) The 2nd:4th digit ratio and asymmetry of hand performance in Jamaican children. Laterality. 5(2): 121-132. https://doi.org/10.1080/135765000396744

29. Manning JT, Peters M (2009) Digit ratio (2D:4D) and hand preference for writing in the BBC internet study. Laterality. 14(5):528-540. https://doi.org/1 $0.1080 / 13576500802637872$

30. Muller DC, Baglietto L, Manning JT, McLean C, Hopper JL, English DR, Giles GG, Severi G (2012) Second to fourth digit ratio (2D:4D), breast cancer risk factors, and breast cancer risk: a prospective cohort study. Br J Cancer 107(9):1631-1636. https://doi.org/10.1038/bjc.2012.418

31. Lu H, Ma Z, Zhao J, Huo Z (2015) Second to fourth digit ratio (2D:4D) and coronary heart disease. Early Hum Dev 91(7):417-420. https://doi.org/10.101 6/j.earlhumdev.2015.04.009

32. Yang K, Ding $X$, Zhou Z, Shi X (2018) 2D:4D ratio differs in ischemic stroke: a single center experience. Transl Neurosci 9:142-146. https://doi.org/10.1515/tnsci-2018-0021

33. Kasielska-Trojan A, Manning JT, Antczak A, Dutkowska A, Kuczynski W, Sitek A et al (2020) Digit ratio (2D:4D) in women and men with lung cancer. Sci Rep 10(1):11369. https://doi.org/10.1038/s41598-020-68239-0

34. Geschwind N, Galaburda AM (1985) Cerebral lateralization. Biological mechanisms, associations, and pathology: Il. A hypothesis and a program for research. Arch Neurol 42(6):521-552. https://doi.org/10.1001/archneur.1985.04060060019009

35. Krajmer P, Spajdel M, Kubranska A, Ostatnikova D (2011) 2D:4D finger ratio in Slovak autism spectrum population. Bratisl Lek Listy 112(7):377-379

36. Mackus M, de Kruijff D, Otten LS, Kraneveld AD, Garssen J, Verster JC (2017) The 2D : 4D digit ratio as a biomarker for autism Spectrum disorder. Autism Res Treat 2017:1048302-1048305. https://doi.org/10.1155/2017/1048302

37. Lee SHF, Aziz SA, Hamid M, Lim YC, Koh D, Chaw LL (2021) 2D:4D ratio and autism Spectrum disorder in Brunei Darussalam. J Autism Dev Disord. https://doi.org/10.1007/s10803-021-04899-9

38. Al-Zaid FS, Alhader AA, Al-Ayadhi LY (2015) The second to fourth digit ratio (2D:4D) in Saudi boys with autism: a potential screening tool. Early Hum Dev 91(7):413-415. https://doi.org/10.1016/j.earlhumdev.2015.04.007

39. Petralia MC, Sagone E, Coco M, Gueli R, Di Gregorio G, Coco LSG et al (2018) The 2D:4D ratio is associated with performance in the 'TEACCH program' of subjects with autism spectrum disorder. Exp Ther Med 16(6): 5373-5375. https://doi.org/10.3892/etm.2018.6834

40. Manning JT, Baron-Cohen S, Wheelwright S, Sanders G (2001) The 2nd to 4th digit ratio and autism. Dev Med Child Neurol 43(3):160-164. https://doi. org/10.1111/j.1469-8749.2001.tb00181.x

41. Myers L, Van't Westeinde A, Kuja-Halkola R, Tammimies K, Bolte S (2018) 2D:4D ratio in neurodevelopmental disorders: a twin study. J Autism Dev Disord 48(9):3244-3252. https://doi.org/10.1007/s10803-018-3588-8

42. Knussmann. Somatometrie. Antropologie Handbuch der vergleichenden Biologie des Menschen Stuttgart: G Fischer Verlag. 1988
43. Kasielska-Trojan A, Antoszewski B (2015) Can digit ratio (2D:4D) studies be helpful in explaining the aetiology of idiopathic gynecomastia? Early Hum Dev 91(1):57-61. https://doi.org/10.1016/j.earlhumdev.2014.12.001

44. Manning JT, Fink B, Neave N, Caswell N (2005) Photocopies yield lower digit ratios (2D:4D) than direct finger measurements. Arch Sex Behav 34(3):329_ 333. https://doi.org/10.1007/s10508-005-3121-y

45. NN ER, Morais RN, Manning JT (2016) Direct versus indirect measurement of digit ratio (2D:4D): a critical review of the literature and new data. Evol Psychol 14(1):147470491663253. https://doi.org/10.1177/1474704916632536

46. Moran MD (2003) Arguments for rejecting the sequential Bonferroni in ecological studies. Oikos. 100(2):403-405. https://doi.org/10.1034/j.1600-0706.2003.12010.x

47. Zadzinska E, Rosset I (2013) Pre-natal and perinatal factors affecting body mass index in pre-pubertal polish children. Ann Hum Biol 40(6):477-484. https://doi.org/10.3109/03014460.2013.806589

48. Zadzinska E, Sitek A, Rosset I (2016) Relationship between pre-natal factors, the perinatal environment, motor development in the first year of life and the timing of first deciduous tooth emergence. Ann Hum Biol 43(1):25-33. https://doi.org/10.3109/03014460.2015.1006140

49. Barker DJ (1990) The fetal and infant origins of adult disease. BMJ. 301(6761):1111. https://doi.org/10.1136/bmj.301.6761.1111

50. Manning JT, Bundred PE (2000) The ratio of 2 nd to 4th digit length: a new predictor of disease predisposition? Med Hypotheses 54(5):855-857. https:// doi.org/10.1054/mehy.1999.1150

51. Kasielska-Trojan A, Sitek A, Antoszewski B (2019) Second to fourth digit ratio (2D:4D) in women with carpal tunnel syndrome. Early Hum Dev 137:104829. https://doi.org/10.1016/j.earlhumdev.2019.104829

52. Rahman AA, Lophatananon A, Stewart-Brown S, Harriss D, Anderson J, Parker T et al (2011) Hand pattern indicates prostate cancer risk. Br J Cancer 104(1):175-177. https://doi.org/10.1038/sj.bjc.6605986

53. Kyriakidis I, Papaioannidou P, Pantelidou V, Kalles V, Gemitzis K (2010) Digit ratios and relation to myocardial infarction in Greek men and women. Gend Med 7(6):628-636. https://doi.org/10.1016/j.genm.2010.11.008

54. Kasielska-Trojan A, Stabryla P, Antoszewski B (2017) Digit ratio (2D:4D) and postoperative pain perception. Early Hum Dev 110:25-30. https://doi.org/1 0.1016/j.earlhumdev.2017.05.003

55. Vetvik KG, MacGregor EA (2021) Menstrual migraine: a distinct disorder needing greater recognition. Lancet Neurol 20(4):304-315. https://doi.org/1 0.1016/S1474-4422(20)30482-8

56. Chai NC, Peterlin BL, Calhoun AH (2014) Migraine and estrogen. Curr Opin Neurol 27(3):315-324. https://doi.org/10.1097/WCO.0000000000000091

57. Geschwind N, Behan P (1982) Left-handedness: association with immune disease, migraine, and developmental learning disorder. Proc Natl Acad Sci U S A 79(16):5097-5100. https://doi.org/10.1073/pnas.79.16.5097

58. La Pegna GB, Quatrosi G, Vetri L, Reina F, Galati C, Manzo ML et al (2021) Migraine and handedness. Neurological Sciences : Official Journal of the Italian Neurological Society and of the Italian Society of Clinical Neurophysiology 42(7):2965-2968. https://doi.org/10.1007/s10072-021-05111-7

59. Pourabolghasem $S$, Najmi S, Arami MA (2009) Polycystic ovary syndrome and migraine headache, is there any correlation? Eur Neurol 61(1):42-45. https://doi.org/10.1159/000165349

60. Glintborg D, Hass Rubin K, Nybo M, Abrahamsen B, Andersen M (2015) Morbidity and medicine prescriptions in a nationwide Danish population of patients diagnosed with polycystic ovary syndrome. Eur J Endocrinol 172(5): 627-638. https://doi.org/10.1530/EJE-14-1108

61. Sir-Petermann T, Maliqueo M, Angel B, Lara HE, Perez-Bravo F, Recabarren SE (2002) Maternal serum androgens in pregnant women with polycystic ovarian syndrome: possible implications in prenatal androgenization. Hum Reprod 17(10):2573-2579. https://doi.org/10.1093/humrep/17.10.2573

62. Artero-Morales M, Gonzalez-Rodriguez S, Ferrer-Montiel A (2018) TRP channels as potential targets for sex-related differences in migraine pain. Front Mol Biosci 5:73. https://doi.org/10.3389/fmolb.2018.00073

63. van Oosterhout WPJ, Schoonman GG, van Zwet EW, Dekkers OM, Terwindt GM, MaassenVanDenBrink A, Ferrari MD (2018) Female sex hormones in men with migraine. Neurology. 91(4):e374-ee81. https://doi.org/10.1212/ WNL.0000000000005855

64. Shields LBE, Seifert T, Shelton BJ, Plato BM (2019) Testosterone levels in men with chronic migraine. Neurol Int 11(2):8079. https://doi.org/10.4081/ni.2019.8079

\section{Publisher's Note}

Springer Nature remains neutral with regard to jurisdictional claims in published maps and institutional affiliations. 